\title{
Genetic Studies in French Guiana Populations: Synthesis
}

Stéphane Mazières, ${ }^{1}$ André Sevin, ${ }^{1}$ Françoise Bonnet, ${ }^{2}$ Eric Crubézy, ${ }^{1}$ Francisco M. Salzano, ${ }^{3}$ Georges Larrouy ${ }^{1}$

${ }^{1}$ Centre d'Anthropologie, Université Paul Sabatier, CNRS, UMR 8555, 31000 Toulouse, France

${ }^{2}$ Institut Claudius Regaud, 20-24 rue du Pont Saint-Pierre, 31052 Toulouse, France

${ }^{3}$ Departamento de Genética, Instituto de Biociências, Universidade Federal do Rio Grande do Sul, Caixa Postal 15053, $91501-970$ Porto Alegre, RS, Brazil

Abbreviated title: FRENCH GUIANA INDIANS GENETICS

KEY WORDS Blood genetic markers; French Guiana Natives

Number of text pages: 14

75 references, 3 tables, 5 figures

Grant sponsor : Direction Régionale des Affaires Culturelles en Guyane; Grant sponsor:

Ministère de la Culture; Grant sponsor: Centre National de la Recherche Scientifique.

Correspondence to:

Prof. Eric Crubézy, Centre d'Anthropologie, Faculté de Médecine, 37, allées Jules Guesde, 31000 Toulouse, France. Telephone number: (00 33) 056114 5980; Fax number: (00 33) 05 6114 5979; E-mail: crubezy.eric@free.fr 
ABSTRACT Twelve blood group and protein systems from a total of 819 individuals from six tribal groups (Apalaí-Wayana, Emerillon, Kaliña, Palikur Wayampi and Wayana) living in French Guiana and Brazil were compared with each other and integrated with previous results from 17 other South Amerindian populations studied for the same genetic markers. Using correspondence analysis, map methodologies and maximum linkage cluster analysis developed with the UPGMA method, we attempted to establish the genetic position of these tribes among South American Indians. Peripheral positions for the Emerillon and the Palikur were observed. Ethnohistorical data in French Guiana suggest that a strong founder effect for the former and endogamy for the latter could have generated the genetic differentiation of these two ethnic groups. However, when considered in a wider context, all French Guiana Natives cluster together, in a intermediate position as compared to 17 other Amerindian groups studied for the comparison. 
Since the first genetic studies on the Yanomama, the Makiritare and their neighboring populations from Venezuala and northern Brazil (Layrisse et al., 1962; Arends et al., 1967, 1970; Chagnon et al., 1970; Gershowitz et al., 1970, 1972; Ward et al., 1970, 1975; Ward and Neel, 1976; Weitkamp and Neel, 1970; Neel et al., 1977, 1980; Smouse and Ward, 1978; Neel, 1978), the Amazonian Native populations have gathered much interest from the genetic point of view and reports are nowadays numerous for the classical markers (Matson et al.,1968; Kirk et al., 1974; Geerdink et al., 1974a,b; Black et al., 1988; Callegari-Jacques and Salzano, 1989; Cavalli-Sforza et al., 1994; Callegari-Jacques et al., 1994; Salzano et al., 1988, 1997a,b; Olsson et al., 1998; Santos et al., 1998 ; Battilana et al., 2002; Barjas-Castro et al., 2003). Recently, molecular genetics is also yielding inferences for the present and past societies of this peculiar area of South America (Ribeiro-dos-Santos et al., 1996; Bortolini et al., 1998; Fagundes et al., 2002; Dornelles et al., 2004, 2005; Kohlrausch et al., 2005).

Primary data concerning the French Guiana Indians have been collected as early as the 1960's (Larrouy et al., 1964a,b; Bois and Feingold, 1972; Daveau et al., 1975; Tchen et al., 1978a,b, 1981; Dugoujon et al., 1994 a,b, 1995); nevertheless, they have been unequally examined as compared to other South American Indian populations. Indeed, no relevant DNA studies are available for these populations. In addition, works that have been reported about the genetic relationships of South American populations have mostly dealt with French Guiana hinterland tribes (O’Rourke and Suarez, 1985; Black et al., 1988; Salzano et al., 1988; Callegari-Jacques and Salzano, 1989; Callegari-Jacques et al., 1994; Luiselli et al., 2000), so that no analysis including all five French Guiana Indians has ever been performed.

We recently started a long-range investigation of French Guiana populations with molecular markers, and to set the background we reviewed the data for blood group and protein systems among five French Guiana and one Brazilian Amerindian groups. The present study is the first to include the two populations living on the French Guiana coast. These six populations were then compared with 17 others examined for the same genetic markers, and the following questions were addressed: 1) What are the genetic relationships between all French Guiana Natives and the neighboring Apalaí-Wayana? and 2) What is the genetic position of French Guiana populations, including coastal groups, in South America? 


\section{MATERIALS AND METHODS}

\section{History and demography}

French Guiana is characterized by clear geographic and demographic distinctions. The coast, where $90 \%$ of the population lives, consists of narrow sandy offshore stretches flanked by mudflats. The rest of the country is covered by rainforest and is sparsely populated. Ethnological and demographic data of French Guiana Amerindians obtained before 1947 are generally inaccurate. The earliest documents date from the end of the $16^{\text {th }}$ century, and most of them originate from Jesuit missions. Recent data derive essentially from the works of Hurault (1965), Bois (1967), and Grenand and Grenand (1978, 1979, 1985).

Their demographic history has been established and reveals the presence of about 9500 individuals in the coastal part of French Guiana in the $17^{\text {th }}$ century, a number that began to decrease to reach less than 500 in the second half of the $18^{\text {th }}$ century. Data related to the interior show the same pattern. Three thousand Wayana and 400 Emerillon were estimated to live in 1770, and 6000 Wayampi in 1824 before diminishing to a total of 900 persons in the middle of the $20^{\text {th }}$ century. Nowadays, all populations are on the increase, with 3300 Amerindians estimated to live in French Guiana in the 1980's (Grenand and Grenand, 1979).

\section{Interior populations}

Wayampi These Tupi-Guarani Indians came from the lower Amazonian region and Xingu area in Brazil at the end of the $18^{\text {th }}$ century (Grenand and Grenand, 1985). A total of 501 persons are currently living in two communities along the upper Oyapock river. Of these, 283 inhabit three villages near Trois-Sauts, and 218 two villages in the Camopi area. The Wayampi living in Trois-Sauts are in contact with related communities from Brazil. The Wayampi system of family relationships is based on preferential marriages between cross cousins or between classificatory non-cousins. A previous genetic report showed a high degree of endogamy and very limited crossbreeding with non-Indian groups (Dugoujon et al., 1994a).

Emerillon These Tupi-speaking Indians have been settled in French Guiana since the $16^{\text {th }}$ century. Grenand and Grenand (1979) noted that the Emerillon escaped extinction in the 1950 's when they were reduced to 52 individuals only. As a consequence, they constitute the smallest group of French Guiana Indians with barely more than 120 persons estimated in the Camopi area and along the Oyapock and Maroni rivers (Dugoujon et al., 1994a).

Wayana This Indian group, almost completely isolated until the middle of the $19^{\text {th }}$ century, was less affected by epidemics. Consequently, it constitutes the most numerous native group among the Indian tribes of the hinterland (Grenand and Grenand, 1979); some 
550 persons are scattered over ten villages along the upper Maroni and Litani rivers. The Wayana language is classified in the Carib linguistic family. Their system of family relationships is based on preferential marriages between classificatory non-cousins that results in a theoretically high degree of consanguinity (Grenand and Grenand, 1985). This system however is counterbalanced by the custom requiring that sons-in-law come from outside the village.

Apalai-Wayana The Apalaí-Wayana inhabit the Paru river area, in Brazil, next to the frontier with French Guiana. They result from a fusion that occurred at the end of the $19^{\text {th }}$ century between two Carib tribes, the Apalaí and the Wayana. Their population is estimated as 260 persons. The social structure of the Carib tribes is usually matrilocal, but the ApalaíWayana differ from this pattern by showing a patrilocal structure (Salzano et al., 1988).

\section{Coastal populations}

Three groups inhabit the littoral of French Guiana and Brazil (State of Amapá). One of them, the Arawak-Lokono, are fairly acculturated and the other two are described below.

Kaliña Also known as Galibi, these Carib-speaking Indians are the largest group of French Guiana, with approximately 2000 persons living in the northwestern part of the country, near the estuary of the Maroni and Mana rivers. About 5000 Kaliña previously occupied the northern part of French Guiana, but epidemics reduced this population to 200 in 1790. The Kaliña communities are organized around patriarchal units in which the sons-inlaw owe obedience to the family head. Previous studies showed that the Kaliña have an important degree of non-Indian admixture compared to the other tribes (Larrouy et al., 1964a).

Palikur The Palikur were the first inhabitants of the coastal region. This Arawakspeaking group may have come from the upper Xingu, in the Southwest part of the State of Pará (Brazil). Vicente Pinzon first identified them in 1550 at the western side of the Amazon mouth, and in the $19^{\text {th }}$ century Henri Coudreau registered their presence at the Urucauá river, in the Oyapock region of Brazil (Arnaud, 1980). Nowadays, 400 Palikur occupy the Oyapock estuary in French Guiana, while 600 Palikur live in the Urucauá river region, in Brazil. The social structure of this ethnic group is made up of clans, and unions are only allowed between them.

\section{Samples}

Our study includes samples from 683 French Guiana individuals distributed as follows : 42 Emerillon from the Camopi and Tampock rivers, 81 Wayampi from Camopi and Trois-Sauts, 304 Palikur from the Oyapock estuary, 156 Kaliña and 100 Wayana (Fig. 1). All samples 
were collected during the 1964 to 1985 missions, led by one of us (G.L.), under the auspices of the Centre National de la Recherche Scientifique (Centre d'Hémotypologie, Toulouse, France). All blood samples were collected with vacutainers containing EDTA or ACD anticoagulants and conserved in isothermal boxes at $4{ }^{\circ} \mathrm{C}$.

\section{Methods}

Each of the 683 specimens was examined for 12 blood systems, six immunologic (MN, Ss, Rhesus, P, Diego, Duffy), four serum (GM, KM, haptoglobin, Group Specific Component), and two enzyme (PGM1, ACP) markers. These 12 systems were chosen due to their high degree of polymorphism. All analyses were performed at Toulouse's Hemotypology Laboratory. The Gm and Km allotypes were determined by the classical hemagglutination inhibition method, with human antisera (Field and Dugoujon, 1989). The transferrin, Rhesus "d", PGM2 and G2M*23 markers were excluded from the statistical analysis due to their monomorphism in South American Indians (Tchen et al., 1978a,b, 1981; Salzano et al., 1988). The ABO and Kell systems, which are also monomorphic in South American Indians, were included to evaluate admixture.

Data for the ABO system in all five populations derive from Larrouy et al. (1964a) results; the Gm haplotypes in the Emerillon, Wayampi and Wayana come from Dugoujon et al. (1994a,b, 1995) and those for the rhesus system in the Wayampi from Tchen et al. (1981). In addition, 136 Apalaí-Wayana (Fig. 1) previously described by Salzano et al., (1988) were included in the analysis.

\section{South American Natives included for comparison}

A total of 17 other South Amerindian tribes (Fig. 1) were considered using results from the literature (Black et al., 1988; Callegari-Jacques et al., 1994; Salzano et al., 1997a,b; Santos et al., 1998; Luiselli et al., 2000; Goicoechea et al., 2001a; Battilana et al., 2002). These tribes are briefly described below. The numbers in parentheses represent sample sizes.

In this study, the Tupi linguistic family is the most represented. The Cinta Larga (105) are actually a community composed of four Tupi-Mondé subgroups: Mã, Kaki, Kabã and Ubiei (Callegari-Jacques et al., 1994). Also known as Matetamãe, these hunter-gatherers are estimated to number 655 persons scattered in six villages, at the border of the states of Rondonia and Mato Grosso, in Brazil. The Karitiana (87) speak a language of the TupiAriken family, and are estimated to number 129 persons (Callegari-Jacques et al., 1994). For the Surui (53), only those located in the Aripuanã Indian Park, at the border between the states of Rondônia and Mato Grosso, were analyzed (Callegari-Jacques et al., 1994). These Tupispeaking Indians are also referred to as Surui-Paiter. 
The following tribes also speak a Tupi language but belong to the large Tupi-Guarani subfamily. The Tenharim (23) were previously mentioned as "Parintintin" (Métraux and Nimuendaju, 1963). About 360 Tenharim are estimated to live in the southern part of the state of Amazonas, in Brazil (Santos et al., 1998). Like all the Amazonian tribes, they practice agriculture but also rubber gathering. The Urubu-Kaapor (193) are estimated to number 710 persons distributed over 17 villages in the northwest of the state of Maranhão, Brazil. Alternative names exist to designate them: "Ka'apor", "Kaaporté" or "Kambo" (Black et al., 1988). The Asurini (150) are divided in two communities: Akwã-Asurini, numbering about 150 persons in the lower Araguaia river, in the Brazilian state of Pará; and Asurini of Xingu, with about 54 persons, at the margins of the Xingu river; both speak a Tupi language (Black et al., 1988). The Parakanã (117) live just at the south of the Asurini of Xingu. The Aché (99) are a Paraguayan tribe of the Tupi linguistic family (Battilana et al., 2002). They are also known under the names of "Guayakí", "Guoyagui", or "Axe" and are found in the forests of eastern Paraguay (Métraux and Baldus, 1963). The Guarani (27) inhabit the region between the Paraguay and Paraná rivers and constitute the southernmost enclave of the very large and widely distributed Tupi linguistic family. About 3,000 Guarani Indians currently live in southern Brazil. Of these, two-thirds speak mbya and one-third the ñandeva language. The Guarani sample included in our study was obtained among mbya-speaking individuals (Salzano et al., 1997b; Battilana et al., 2002).

The Kararaô, the Caingang, and the Xavante represent the Gê linguistic group in this study. The Kararao (32) are a Cayapo subgroup. They inhabit the margins of the Xingu river, and suffered in the past the disastrous consequences of epidemics: at the time of the work of Callegari-Jacques et al., (1994), only 36 individuals were numbered. The Caingang (227) are, along with the Guarani, one of the largest tribes of southern Brazil with around 15,000 individuals distributed over 25 localities (Métraux and Baldus, 1963; Salzano et al., 1997b). The 227 individuals studied inhabit two communities located in the county of Laranjeiras do Sul and Manoel Ribas, Brazilian state of Paraná. The Xavante (85), numbering around 10,000 persons, are distributed along several villages in six reservations, in the state of Mato Grosso, Brazil (Salzano et al., 1997a).

Finally, four Argentinean and one Andean populations were also included in the analysis. The Quechua (141) are the only representatives of Andean populations in this analysis. Those examined are from the Tayacaja Province (Luiselli et al., 2000). The Choroti (23), Mataco (90) and Toba speak a language classified within the Mataco-Guaicuru stock and occupy the northern Chaco region (Goicoechea et al., 2001b). The Mapuche (239) speak a language of 
the Araucanian group classified within the Southern Andean division. They arrived to Argentina from Chile in the $17^{\text {th }}$ century and their population is now estimated at 50,000 (Goicoechea et al., 2001a).

\section{Statistical analysis}

Allele frequencies were analyzed for the Hardy-Weinberg equilibrium test, and heterozygosity for each of the 12 blood group and protein systems was then calculated with the formula: $H=1-\sum_{i}\left(p_{i}^{2}\right)$. The genetic relationships among populations were successively considered by correspondence (Greenacre, 1984), color-graded maps (Piazza et al., 1981) and maximum linkage cluster analysis (dendrograms). All correspondence analyses (CA) were performed using the SPAD software (Ward, 1963) and calculated using Rogers' distance (CISIA, 1987). The CA allow a visual interpretation of the genetic differences between populations and indicates the relative weight of each allele to the observed dispersion. When added to geographic coordinates, a color-graded map (Piazza et al., 1981) is obtained for each PC axis, using the UNIRAS A/S SOBERG (Denmark) program. In each map, the values of the color-graded scale indicate the coordinates of the populations in this axis. The purpose is to reduce the dimensionality of the data matrix of gene frequencies $x$ populations using an interpolation or smoothing algorithm so that scores distribution can be mapped onto the study area. Afterwards, the genetic variation thus obtained can be confronted with ethnohistorical hypotheses (Cavalli-Sforza et al., 1994). Criticisms have been made in relation to the appropriateness of this approach (Sokal et al., 1999), but they were properly answered by Rendine et al. (1999). Dendrograms were then established using the UPGMA method and Cavalli-Sforza's distance (Cavalli-Sforza and Edwards 1967), with the PHYLIP (Felsenstein, 2002) and TREEVIEW (Page, 1996) programs. The reliability of the trees was tested by bootstrap replications, following Hedges (1992).

\section{RESULTS}

Table 1 presents the allele frequencies for the 10 genetic systems plus ABO. The HardyWeinberg equilibrium tests performed in the codominant systems listed in this table and in Table 2 generally yielded non-significant results, with three exceptions. Since the total number of tests done was 86 , this figure is not much different from that expected by chance alone. Random deviations are expected with the sample sizes considered here. Generally only $A B O^{*} 0$ is observed in Amerindian groups (Matson et al., 1968; Tchen et al., 1981; Salzano et al., 1988; Olsson et al., 1998; Santos et al., 1998), but $A B O^{*} A$ or $A B O^{*} B$ alleles were found in 
low frequencies among the Palikur, Wayampi and Kaliña. Allele $K_{e l l}^{*} K$, of the Kell system, was only found in low frequency among the Kaliña (data not shown).

As for the 10 other systems listed in Table 1, the most marked intertribal differences occur in the MN system $\left(M N^{*} M\right.$ : Emerillon, 0.47; Apalaí-Wayana, 0.91) and haptoglobin $\left(H P^{*} 1\right.$ : Wayampi, 0.50; Palikur, 0.84), while in ACP this difference is of $11 \%$ (Kaliña, 0.78; Emerillon, 0.89). No tribe presents especially remarkable differences in gene frequencies compared to the others. In terms of heterozygosity, as expected since four alleles were identified in it against two in all others, the Rhesus system showed the highest average (0.59), while PGM1 presented the lowest (0.20).

Two levels of analysis for the Gm system are displayed in Table 2, due to the number of sera included in the analysis. $G m^{*} 1,17 ; 21 *$ and $G m^{*} 1,2,17 ; 21 *$ are the commonest haplotypes and represent more than $90 \%$ of the sample in French Guiana. Exceptions are the Emerillon and Kaliña, in which they represent $78 \%$ of the haplotypes present. $K m^{*} 1,2$ is higher than $K m * 3$ only among the Palikur and Wayampi. The Kaliña and Wayana, both speakers of a Carib language, have nearly the same frequency for $K m^{*} 1,2(0.34$ and 0.35$)$. When the average heterozygosity among tribes is calculated, the highest value (0.54) occurs in the Kaliña and the lowest (0.36) in the Emerillon.

Since the Apalaí-Wayana were not examined for the Diego system, this blood group was not included in the comparison analysis. The data related to the remaining 11 systems were pooled and subjected to correspondence analysis. Axes 1 and 2 of Figure 2 summarize $64 \%$ of the information. Most of the score distribution of Figure 2 is stretched by the $P G M 1 * 2$, $M N^{*} N$, and $R H^{*} R o$ alleles and by the $G m^{*} 1,17 ; 5^{*}, G m^{*} 3 ; 5^{*}$ and $K m^{*} 1,2$ haplotypes. Axis 1 separates the Palikur and Apalaí-Wayana from the Emerillon whereas the Kaliña, Wayampi and Wayana stand in a central position. Axis 2 separates the Palikur from the Apalaí-Wayana. However, when the data related to these populations are considered together with the 17 other assembled for comparison (Figure 3) the relationships of the six groups among themselves change somewhat and what should be stressed is their similarity, not the differences. The synthetic maps displayed in Figures 4 and 5 present in a graphical way the results concerning axes 1 and 2 of the previous analysis. Both show two cores, one composed by the central Amazonian tribes and the second by the Chaco populations, with the French Guiana groups presenting intermediate values.

Additional analyses were performed using the dendrogram approach. However, the bootstraps obtained were generally low, as would be expected if the French Guianans could 
not be clearly differentiated from the other populations. Therefore, these results are not shown.

\section{DISCUSSION}

The six populations considered show certain general Amazonian characteristics, like the higher frequency of $R H^{*} R I$ as compared to $R H^{*} R 2$ (Tchen et al., 1981; Black et al., 1988; Salzano et al., 1988; Blanchard, 1991; Callegari-Jacques et al., 1994) and the high frequencies of $D I^{*} A$, which is a rare allele in other South America Indians and is absent in European populations (Tchen et al., 1981; Cavalli-Sforza et al., 1994). However, $\mathrm{Kell}^{*} K^{+}, A B O^{*} A$ and $A B O * B$ alleles as well as $G m * 3,5 *$ and $G m * 1,17,5 *$ haplotypes have been encountered in our samples. They have certainly been introduced by non-Indian mating, especially in the Kaliña whose proximity with Creole and Noir-Marron people settled nearby since the end of the $18^{\text {th }}$ century (Moomou, 2004; Price and Price, 2004) may favor gene exchanges (Larrouy et al., 1964a; Daveau et al., 1975).

When the six six populations are considered in isolation from the rest (Fig. 2) the Wayana, Wayampi, Kaliña and Apalaí-Wayana are grouped together, while the Palikur and Emerillon show some differentiation. The first point to be noted is that the first named four populations belong to two different linguistic stocks. The Kaliña, Wayana and Apalaí-Wayana speak a Carib language whereas the Wayampi are Tupi-Guarani speakers. Their genetic similarity may imply gene flow among them, emphasizing the role of geographic proximity in gene exchanges, as stressed by S. Wright's neighborhood model. Notably, the Wayana are known to be a mobile group that frequently visit the Wayampi territory (Grenand and Grenand, 1985).

As for the peripheral positions of the Palikur and Emerillon, admixture can be ruled out for the Palikur, because they do not present as many non-Indian components as the Kaliña do. Thus, another explanation should be suggested. Originating from the high Xingu area, the Palikur were the first to settle in the region, around 100 AD (Grenand and Grenand, 1987). They entered the area by a peripheral migratory way via the southeast through the Brazilian Amapá, before settling in the mouth of the Oyapock. Unique French Guiana ethnic group of the Arawak linguistic family, the Palikur are distinguishable by their social structure organized in clans. Such social structures usually lead to endogamy preventing the population from contacts with outsiders, conditioning higher frequencies of the $K m^{*} 1,2, G m^{*} 1,2,17 ; 21^{*}$, and $H p^{*} I$ alleles (Table 1 and Fig. 2). In addition, previous archeological studies linked the Palikur to the Ariste ceramic culture, whose geographic location is restricted to northern 
Amapá. This ceramic type is assigned to a pan-tribal autonomous population, refractory to any intrusion, of which the Palikur may be the descendants (Rostain, 1994).

The other group that departs from the pattern shown by the French Guiana Natives is the Emerillon. Their genetic identity is distinguished by the absence of the $P G M 1^{* 2}$ allele, low values of $K m^{*} 1,2, G m^{*} 1,2,17 ; 21^{*}$ and $S s^{*} s$ variants, as well as the prevalence of $G m^{*} 3,5^{*}$, $G m^{*} 1,17,5 *$ and $G m^{*} 1,17 ; 10,11,13,15,16$ haplotypes (Tables 1 and 2). Ethnological data indicated that the Emerillon underwent the most dramatic demographic event of the whole French Guiana, when they escaped extinction in the 1950's with only some fifty people remaining (Grenand and Grenand, 1979). Therefore, stochastic forces could have been stronger due to their smaller effective size, substantially altering their gene pool.

In a wider context, however, the French Guiana and one Brazilian groups considered here show more similarities than differences. The question is, are the markers tested informative enough, are the populations too similar, or both? Previous attempts with the same kind of markers and more genetic systems did not distinguish clear clusters of populations in the geographic area studied here (O'Rourke and Suarez, 1985; Salzano et al., 1997a). Our opinion is that this homogeneity should be tested with additional, molecular markers, and steps in this direction are already being taken by our research group.

\section{CONCLUSION}

The French Guiana Natives and their Apalaí-Wayana neighbors show some genetic distinctions among themselves, especially the interior Emerillon and the coastal Palikur. These differences could have been arisen by special circumstances related to their culture or demographic history. However, when compared to a wider set of 17 other South American groups, they occupy an intermediate position, placing them well within the general pattern of Amerindian genetics. 


\section{LITERATURE CITED}

Arends T, Brewer G, Chagnon N, Gallango ML, Gershowitz H, Layrisse M, Neel J, Shreffler

D, Tashian R, Weitkamp L. 1967. Intratribal genetic differentiation among the Yanomama Indians of southern Venezuela. Proc Natl Acad Sci USA 57:1252-1259.

Arends T, Weitkamp LR, Gallango ML, Neel JV, Schultz J. 1970. Gene frequencies and microdifferentiation among the Makiritare Indians. II. Seven serum protein systems. Am J Hum Genet 22:526-532.

Arnaud E. 1980. O protestantismo entre os ìndios Palikur do Rio Urucauá (Oiapoque, Brazil) - Notìcia preliminar. Rev Antropol (São Paulo) 23: 99-102.

Barjas-Castro ML, Soares MC, Menezes RC, Carvalho MH, Costa FF, Saad ST. 2003. ABO blood group in Amerindians from Brazilian Amazon. Ann Hum Biol 30:220-224.

Battilana J, Bonatto SL, Freitas LB, Hutz MH, Weimer TA, Callegari-Jacques SM, Batzer MA, Hill K, Hurtado AM, Tsuneto LT, Petzl-Erler ML, Salzano FM. 2002. Alu insertions versus blood group plus protein genetic variability in four Amerindian populations. Ann Hum Biol 29:334-347.

Black FL, Santos SEB, Salzano FM, Callegari-Jacques SM, Weimer TA, Franco MHLP, Hutz MH, Rieger TT, Kubo RR, Mestriner MA, Pandey JP. 1988. Genetic variation within the linguistic Tupi group: new data on three Amazonian tribes. Ann Hum Biol 15:337-351.

Blanchard N. 1991. Positionnement suivant les gènes rhésus des populations amérindiennes.

Toulouse : Mémoire de DEA d'Anthropologie, option Anthropologie biologique,

Université Paul Sabatier.

Bois E. 1967. Les Amérindiens de la Haute-Guyane française. Anthropologie, pathologie, biologie. Paris : Editions du C.N.R.S., Desclée Ed.

Bois E, Feingold J. 1972. Genetics of blood uric acid levels: study of three Amerindian tribes of Upper Guyana. Ann Genet 15:257-264.

Bortolini MC, Baptista C, Callegari-Jacques SM, Weimer TA, Salzano FM. 1998. Diversity in protein, nuclear DNA, and mtDNA in South Amerinds - agreement or discrepancy? Ann Hum Genet 62:133-145.

Callegari-Jacques SM, Salzano F.M. 1989. Genetic variation within two linguistic Amerindian groups - relationship to geography and population size. Am J Phys Anthropol 79:313-320 
Callegari-Jacques SM, Salzano FM, Weimer TA, Hutz MH, Black FL, Santos SEB, Franco MHLP, Guerreiro JF, Mestriner MA, Pandey JP. 1994. Further blood genetic studies on Amazonian diversity - data from four Indian groups. Ann Hum Biol 21:465-481.

Cavalli-Sforza LL, and Edwards AWF. 1967. Phylogenetic analysis: models and estimation procedures. Evolution 32:550-570.

Cavalli-Sforza LL, Menozzi P, Piazza A. 1994. The history and geography of human genes.

Princeton: Princeton University Press.

Chagnon NA, Neel JV, Weitkamp L, Gershowitz H, Ayres M. 1970. The influence of cultural factors on the demography and pattern of gene flow from the Makiritare to the Yanomama Indians. Am J Phys Anthropol 32:339-349.

CISIA (Centre International des Statistiques et d'Informations Appliquées). 1987. Logiciel SPAD.N@ version 2.0 (Système Portable pour l'Analyse des Données) par Lebart L, Moriveau A, Lambert T, Pleuvret P. Saint-Mandé, France.

Daveau M, Rivat L, Langaney A, Afifi N, Bois E, Ropartz C. 1975. Gm and Inv allotypes in French Guiana Indians. Hum Hered 25:88-92.

Dornelles CL, Battilana J, Fagundes NJR, Freitas LB, Bonatto SL, Salzano FM. 2004.

Mitochondrial DNA and Alu insertions in a genetically peculiar population: the Ayoreo Indians of Bolivia and Paraguay. Am J Hum Biol 16:479-488.

Dornelles CL, Bonatto SL, Freitas LB, Salzano FM. 2005. Is haplogroup X present in extant South American Indians? Am J Phys Anthropol 127: 439-448

Dugoujon JM, Guitard E, Senegas MT, Grenand P, Bois E. 1994a. Gm and Km allotypes in Wayampi, Wayana and Emerillon Indians from French Guiana. Ann Hum Biol 21:335345.

Dugoujon JM, Maurieres P, Grenand P, Bois E. 1994b. Immunoglobulin allotypes (GM and KM) in three Amerindian populations of French Guiana. Gene Geogr 8:13-24.

Dugoujon JM, Mourrieras B, Senegas MT, Guitard E, Sevin A, Bois E, Hazout S. 1995. Genetic diversity (immunoglobulin GM allotypes), linguistic data, and migrations of Amerindian tribes. Hum Biol 67:231-249.

Fagundes NJ, Bonatto SL, Callegari-Jacques SM, Salzano FM. 2002. Genetic, geographic, and linguistic variation among South American Indians: possible sex influence. Am J Phys Anthropol 117:68-78.

Felsenstein J. 2002. PHYLIP Phylogeny Inference Package. Version 3.6 (alpha3). Seattle:

Department of Genome Sciences, University of Washington. 
Field LL, Dugoujon JJ. 1989. Immunologic allotyping (Gm-Km) of GAW 5 families. Genet Epidemiol 6:31-34.

Geerdink RA, Nijenhuis LE, van Loghem E, Li Fo Soe E. 1974a. Blood groups and immunoglobulin groups in Trio and Wajana Indians from Surinam. Am J Hum Genet 26:45-53.

Geerdink RA, Bartstra HA, Schillhorn van Veen JM. 1974b. Serum proteins and red cell enzymes in Trio and Wajana Indians from Surinam. Am J Hum Genet 26:581-587.

Gershowitz H, Layrisse M, Layrisse Z, Neel JV, Brewer C, Chagnon N, Ayres M. 1970. Gene frequencies and microdifferentiation among the Makiritare Indians. I. Eleven blood group systems and the $\mathrm{ABH}-\mathrm{Le}$ secretor traits: a note on Rh gene frequency determinations. Am J Hum Genet 22:515-525.

Gershowitz H, Layrisse M, Layrisse Z, Neel JV, Chagnon N, Ayres M. 1972. The genetic structure of a tirbal population, the Yanomama Indians. II. Eleven blood-group systems and the ABH-Le secretor traits. Ann Hum Genet 35:261-269.

Goicoechea AS, Carnese FR, Dejean C, Avena SA, Weimer TA, Franco MH, CallegariJacques SM, Estalote AC, Simoes ML, Palatnik M, Salzano FM. 2001a. Genetic relationships between Amerindian populations of Argentina. Am J Phys Anthropol 115:133-43.

Goicoechea AS, Carnese FR, Dejean C, Avena SA, Weimer TA, Estalote AC, Simoes ML, Palatnik M, Salamoni SP, Salzano FM, Callegari-Jacques SM. 2001b. New genetic data on Amerindians from the Paraguayan Chaco. Am J Hum Biol.13:660-667.

Greenacre MJ. 1984. Theory and application of correspondence analysis. London: Academic Press.

Grenand F, Grenand P. 1978. Les populations amérindiennes de Guyane française. Cayenne: ORSTOM.

Grenand F, Grenand P. 1979. Les Amérindiens de Guyane française aujourd'hui: éléments de compréhension. Bull Soc Americanistes 66:361-382.

Grenand P, Grenand F. 1985. La question amérindienne en Guyane française : eléments d'histoire amérindienne. Ethnies 1:11-17; 23-26.

Grenand F, Grenand P, 1987. La côte d'Amapá, de la bouche de l'Amazone à la baie d'Oyapock, à travers la tradition orale palikur. Bol Mus Par Emílio Goeldi, sér Antropol 3:1-78. 
Hedges SB. 1992. The number of replications needed for accurate estimation of the bootstrap P value in phylogenetic studies. Mol Biol Evol. 9(2):366-9.

Hurault J. 1965. La population des Indiens de Guyane française. Population 20:603-632; 801828.

Kirk RL, McDermid EM, Blake NM, Gajdusek DC, Leyshon WC, MacLennan R. 1974. Blood group, serum protein and red cell enzyme groups of Amerindian populations in Colombia. Am J Phys Anthropol 41:301-316.

Kohlrausch FB, Callegari-Jacques SM, Tsuneto LT, Petzl-Erler ML, Hill K, Hurtado AM, Salzano FM, Hutz MH. 2005. Geography influences microsatellite polymorphism diversity in Amerindians. Am J Phys Anthropol 126:463-470.

Larrouy G, Marty Y, Ruffié J. 1964a. Etude hémotypologique des populations indiennes de Guyane française. Les groupes érythrocytaires. Bull Mem Soc Anthrop Paris 7(11):107117.

Larrouy G, Marty Y, Ruffié J. 1964b. Etude hémotypologique des populations indiennes de Guyane française. Les groupes sériques du système Gm. Bull Mem Soc Anthrop Paris $7(11): 119-123$.

Layrisse M, Layrisse Z, Garcia E, Wilbert J. 1962. Blood group antigens of the Pemon Indians of Venezuela. Am J Phys Anthropol 20:411-420.

Luiselli D, Simoni L, Tarazona-Santos E, Pastor S, Pettener D. 2000. Genetic structure of Quechua-speakers of the Central Andes and geographic patterns of gene frequencies in South Amerindian populations. Am J Phys Anthropol 113 :5-17.

Matson GA, Sutton HE, Swanson J, Robinson A. 1968. Distribution of blood groups among Indians in South America. VI. In Paraguay. Am J Phys Anthropol 29:81-98.

Métraux A, Baldus H. 1963. The Indians of eastern Brazil. In: Steward JH, editor. Handbook of South American Indians. I. The marginal tribes. Washington, DC: Smithsonian Institution. p 381-574.

Métraux A, Nimuendajú C. 1963. The coastal and Amazonian Tupi. In: Steward JH, editor. Handbook of South American Indians. III. The tropical forest tribes. Washington, DC: Smithsonian Institution. p 57-348.

Moomou J. 2004. Le monde des marrons du Maroni en Guyane (1772-1860). La naissance d'un peuple: les Boni. Guyane-Guadeloupe-Martinique: Ibis Rouge.

Neel JV. 1978. The population structure of an Amerindian tribe, the Yanomama. Annu Rev Genet 12:365-413. 
Neel JV, Gershowitz H, Spielman RS, Migliazza EC, Salzano FM, Oliver WJ. 1977. Genetic studies of the Macushi and Wapishana Indians. II. Data on 12 genetic polymorphisms of the red cell and serum proteins: gene flow between the tribes. Hum Genet 37:207-220.

Neel JV, Gershowitz H, Mohrenweiser HW, Amos B, Kostyu DD, Salzano FM, Mestriner MA, Lawrence D, Simoes AL, Smouse PE, Oliver WJ, Spielman RS, Neel JV Jr. 1980. Genetic studies on the Ticuna, an enigmatic tribe of Central Amazonas. Ann Hum Genet $44: 37-54$.

O'Rourke DH, Suarez BK. 1985. Patterns and correlates of genetic variation in South Amerindians. Ann Hum Biol 13:13-31.

Olsson ML, Santos SEB, Guerreiro JF, Zago MA, Chester MA. 1998. Heterogeneity of the O alleles at the blood group ABO locus in Amerindians. Vox Sang 74: 46-50.

Page, R. D. M. 1996. TREEVIEW: An application to display phylogenetic trees on personal computers. Computer Applications in the Biosciences 12: 357-358.

Piazza A, Menozzi P, Cavalli-Sforza L. 1981. The making and testing of geography gene frequency maps. Biometrics 37:635-659.

Price R and Price S. 2004. Les Marrons. La Roque d'Anthéron: Vents d'ailleurs.

Rendine S, Piazza A, Menozzi P, Cavalli-Sforza LL. 1999. A problem with synthetic maps: reply to Sokal et al. Hum Biol 71:15-25.

Ribeiro dos Santos AKC, Santos SEB, Machado AL, Guapindaia V, Zago MA. 1996. Heterogeneity of mitochondrial DNA haplotypes in Pre-Colombian natives of the Amazonian region. Am J Phys Anthropol 101:29-37.

Rostain S. 1994. L'occupation amérindienne ancienne du littoral de Guyane. Paris: Thèse, Université de Paris 1.

Salzano FM, Black FL, Callegari-Jacques SM, Santos SEB, Weimer TA, Mestriner MA, Pandey JP, Hutz MH, Rieger TT. 1988. Genetic variation within a linguistic group: Apalaí-Wayana and other Carib tribes. Am J Phys Anthropol 75:347-356.

Salzano FM, Franco MHLP, Weimer TA, Callegari-Jacques SM, Mestriner MA, Hutz MH, Flowers NM, Santos RV, Coimbra CEA Jr. 1997a. The Brazilian Xavante Indians revisited: new protein genetic studies. Am J Phys Anthropol 104:23-34.

Salzano FM, Callegari-Jacques SM, Weimer TA, Franco MHLP, Hutz MH, Petzl-Erler ML. 1997b. Electrophoretic protein polymorphisms in Kaingang and Guarani Indians of southern Brazil. Am J Hum Biol 9:505-512. 
Santos SEB, Ribeiro-dos-Santos AKC, Guerreiro JF, Santos EJM, Weimer TA, CallegariJacques SM, Mestriner MA, Franco MHLP, Hutz MH, Salzano FM. 1998. New protein genetic studies in six Amazonian Indian populations. Ann Hum Biol 25:505-522.

Smouse PE, Ward RH. 1978. A comparison of the genetic infrastructure of the Ye'cuana and the Yanomama: a likelihood analysis of genotypic variation among populations. Genetics 88:611-631.

Sokal RR, Oden NL, Thomson BA. 1999. A problem with synthetic maps. Hum Biol 71:1-13.

Tchen P, Bois E, Seger J, Grenand P, Feingold N, Feingold JA. 1978a. Genetic study of two French Guiana Amerindian populations. I. Serum proteins and red cell enzymes. Hum Genet 45:305-315.

Tchen P, Seger J, Bois E, Grenand P, Fribourg-Blanc A, Feingold N. 1978b. Genetic study of two French Guiana Amerindian populations.II. Rare electrophoretic variants. Hum Genet 45:317-326.

Tchen P, Bois E, Lanset S, Feingold N. 1981. Blood group antigens in the Emerillon, Wayampi, and Wayana Amerindians of French Guiana. Hum Hered 31:47-53.

Ward RH. 1963. Hierarchical grouping to optimise an objective function. J Am Stat Assoc 58:236-244.

Ward RH, Neel JV. 1970. Gene frequencies and microdifferentiation among the Makiritare Indians. IV. A comparison of a genetic network with ethnohistory and migration matrices; a new index of genetic isolation. Am J Hum Genet 22:538-561.

Ward RH, Gershowitz H, Layrisse M, Neel JV. 1975. The genetic structure of a tribal population, the Yanomama Indians. XI. Gene frequencies for 10 blood groups and the $\mathrm{ABH}-\mathrm{Le}$ secretor traits in the Yanomama and their neighbors; the uniqueness of the tribe. Am J Hum Genet 27:1-30.

Ward RH, Neel JV. 1976 The genetic structure of a tribal population, the Yanomama Indians. XIV. Clines and their interpretation. Genetics 82:103-121.

Weitkamp L, Neel JV. 1970. Gene frequencies and microdifferentiation among the Makiritare Indians. III. Nine erythrocyte enzyme systems. Am J Hum Genet 22:533-537. 
TABLE1. Allele frequencies and heterozygosity for five French Guiana and one Brazilian Native populations studied for 11 blood systems

\begin{tabular}{|c|c|c|c|c|c|c|c|}
\hline \multirow[b]{2}{*}{ Systems } & \multirow[b]{2}{*}{ Alleles } & \multicolumn{6}{|c|}{ Populations } \\
\hline & & $\begin{array}{l}\text { Palikur } \\
(304)\end{array}$ & $\begin{array}{c}\text { Emerillon } \\
(42)\end{array}$ & $\begin{array}{c}\text { Wayampi } \\
(81)\end{array}$ & $\begin{array}{c}\text { Wayana } \\
(100)\end{array}$ & $\begin{array}{c}\text { Kaliña } \\
(156)\end{array}$ & $\begin{array}{c}\text { Apalaí-Wayana } \\
(136)\end{array}$ \\
\hline \multirow[t]{4}{*}{$\mathrm{ABO}$} & $A$ & 0.000 & 0.000 & 0.009 & 0.000 & 0.031 & 0.000 \\
\hline & $B$ & 0.007 & 0.000 & 0.000 & 0.000 & 0.000 & 0.000 \\
\hline & $O$ & 0.993 & 1.000 & 0.991 & 1.000 & 0.969 & 1.000 \\
\hline & $\mathrm{H}$ & 0.013 & 0.000 & 0.018 & 0.000 & 0.060 & 0.000 \\
\hline \multirow[t]{3}{*}{$\mathrm{MN}$} & $M$ & 0.541 & 0.469 & 0.619 & 0.670 & 0.878 & 0.914 \\
\hline & $N$ & 0.459 & 0.531 & 0.381 & 0.330 & 0.122 & 0.087 \\
\hline & $\mathrm{H}$ & 0.497 & 0.498 & 0.472 & 0.442 & 0.214 & 0.158 \\
\hline \multirow[t]{3}{*}{ Ss } & $S$ & 0.207 & 0.523 & 0.477 & 0.500 & 0.308 & 0.290 \\
\hline & $s$ & 0.793 & 0.477 & 0.523 & 0.500 & 0.692 & 0.711 \\
\hline & $\mathrm{H}$ & 0.328 & 0.499 & 0.499 & 0.500 & 0.426 & 0.411 \\
\hline \multirow[t]{5}{*}{ Rhesus } & $C D e(R I)$ & 0.632 & 0.575 & 0.617 & 0.436 & 0.585 & 0.460 \\
\hline & $c D E(R 2)$ & 0.197 & 0.321 & 0.220 & 0.398 & 0.180 & 0.320 \\
\hline & $c D e(R o)$ & 0.005 & 0.012 & 0.008 & 0.085 & 0.029 & 0.100 \\
\hline & $C D E(R z)$ & 0.168 & 0.092 & 0.155 & 0.081 & 0.206 & 0.120 \\
\hline & $\mathrm{H}$ & 0.535 & 0.558 & 0.547 & 0.638 & 0.582 & 0.662 \\
\hline \multirow[t]{3}{*}{$\mathbf{P}$} & $P * 1$ & 0.283 & 0.288 & 0.300 & 0.320 & 0.345 & 0.406 \\
\hline & $p$ & 0.718 & 0.712 & 0.700 & 0.680 & 0.655 & 0.595 \\
\hline & $\mathrm{H}$ & 0.405 & 0.410 & 0.420 & 0.435 & 0.452 & 0.482 \\
\hline \multirow[t]{3}{*}{ Diego } & $D I^{*} A$ & 0.231 & 0.414 & 0.319 & 0.436 & 0.142 & - \\
\hline & $D I * B$ & 0.769 & 0.586 & 0.681 & 0.564 & 0.858 & - \\
\hline & $\mathrm{H}$ & 0.355 & 0.485 & 0.435 & 0.492 & 0.244 & - \\
\hline \multirow[t]{3}{*}{ Duffy } & $F Y^{*} A$ & 0.733 & 0.723 & 0.687 & 0.828 & 0.602 & 0.710 \\
\hline & $F Y^{*} B$ & 0.267 & 0.277 & 0.313 & 0.172 & 0.398 & 0.290 \\
\hline & $\mathrm{H}$ & 0.392 & 0.400 & 0.430 & 0.285 & 0.479 & 0.412 \\
\hline \multirow[t]{3}{*}{ PGM1 } & $P G M I^{*} I$ & 0.892 & 1.000 & 0.889 & 0.829 & 0.926 & 0.696 \\
\hline & $P G M 1 * 2$ & 0.108 & 0.000 & 0.111 & 0.171 & 0.074 & 0.304 \\
\hline & $\mathrm{H}$ & 0.192 & 0.000 & 0.197 & 0.284 & 0.137 & 0.423 \\
\hline
\end{tabular}


Table 1. (Cont.)

\begin{tabular}{|c|c|c|c|c|c|c|c|}
\hline \multirow[b]{2}{*}{ Systems } & \multirow[b]{2}{*}{ Alleles } & \multicolumn{6}{|c|}{ Populations } \\
\hline & & $\begin{array}{c}\text { Palikur } \\
(304)\end{array}$ & $\begin{array}{c}\text { Emerillon } \\
(42)\end{array}$ & $\begin{array}{c}\text { Wayampi } \\
(81)\end{array}$ & $\begin{array}{c}\text { Wayana } \\
(100)\end{array}$ & $\begin{array}{c}\text { Kaliña } \\
(156)\end{array}$ & $\begin{array}{c}\text { Apalaí-Wayana } \\
(136)\end{array}$ \\
\hline \multirow[t]{3}{*}{$\mathrm{ACP}$} & $A C P^{*} A$ & 0.131 & 0.110 & 0.140 & 0.216 & 0.218 & 0.188 \\
\hline & $A C P * B$ & 0.869 & 0.890 & 0.860 & 0.784 & 0.782 & 0.812 \\
\hline & $\mathrm{H}$ & 0.228 & 0.196 & 0.241 & 0.339 & 0.341 & 0.305 \\
\hline \multirow[t]{3}{*}{$\mathrm{GC}$} & $G C^{*} I$ & 0.797 & 0.750 & 0.865 & 0.876 & 0.900 & 0.860 \\
\hline & $G C^{* 2}$ & 0.203 & 0.250 & 0.135 & 0.124 & 0.100 & 0.140 \\
\hline & $\mathrm{H}$ & 0.324 & 0.375 & 0.234 & 0.217 & 0.180 & 0.241 \\
\hline \multirow[t]{4}{*}{ HP } & $H P^{*} 1$ & 0.841 & 0.563 & 0.500 & 0.585 & 0.445 & 0.724 \\
\hline & $H P^{* 2}$ & 0.159 & 0.438 & 0.500 & 0.415 & 0.555 & 0.276 \\
\hline & $\mathrm{H}$ & 0.268 & 0.492 & 0.500 & 0.486 & 0.494 & 0.400 \\
\hline & Average $\mathrm{H}$ & 0.322 & 0.356 & 0.363 & 0.374 & 0.328 & 0.349 \\
\hline
\end{tabular}


TABLE 2. Gm and Km frequencies for five French Guiana and one Brazilian Native populations

\begin{tabular}{|c|c|c|c|c|c|c|}
\hline \multirow[b]{2}{*}{ Alleles or haplotypes } & \multicolumn{6}{|c|}{ Populations } \\
\hline & $\begin{array}{c}\text { Apalaí-Wayana } \\
(136) \\
\end{array}$ & $\begin{array}{c}\text { Palikur } \\
(304) \\
\end{array}$ & $\begin{array}{c}\text { Emerillon } \\
(42) \\
\end{array}$ & $\begin{array}{c}\text { Wayampi } \\
(81) \\
\end{array}$ & $\begin{array}{c}\text { Wayana } \\
(100)\end{array}$ & $\begin{array}{c}\text { Kaliña } \\
(156)\end{array}$ \\
\hline$G M^{*} 1.17 ; 21^{*}$ & 0.716 & 0.615 & 0.661 & 0.802 & 0.742 & 0.470 \\
\hline$G M^{*} 1.2 .17 ; 21^{*}$ & 0.175 & 0.373 & 0.130 & 0.146 & 0.229 & 0.361 \\
\hline$G M^{*} 1.17 ; 5^{*}$ & 0.110 & 0.008 & 0.189 & 0.052 & 0.030 & 0.116 \\
\hline$G M^{*} 3 ; 5^{*}$ & 0.000 & 0.004 & 0.020 & 0.000 & 0.000 & 0.053 \\
\hline$H$ & 0.457 & 0.483 & 0.546 & 0.335 & 0.398 & 0.649 \\
\hline$G M * 1.17 ; 21 R .28$ & - & 0.000 & 0.165 & 0.036 & 0.000 & 0.047 \\
\hline$G M^{*} 1.17 ; 10.11 .13 .15 .16$ & - & 0.000 & 0.159 & 0.024 & 0.018 & 0.115 \\
\hline$G M^{*} 3.5 ; 10.11 .13 .14$ & - & 0.004 & 0.000 & 0.000 & 0.000 & 0.005 \\
\hline$G M^{*} 1.17 ; 5.10 .11 .13 .14$ & - & 0.007 & 0.000 & 0.000 & 0.000 & 0.002 \\
\hline$G M^{*} 1.17 ; 21.28$ & - & 0.598 & 0.550 & 0.771 & 0.745 & 0.470 \\
\hline$G M^{*} 1.2 .17 ; 21.28$ & - & 0.391 & 0.126 & 0.169 & 0.237 & 0.361 \\
\hline$H$ & & 0.490 & 0.629 & 0.375 & 0.389 & 0.633 \\
\hline$K M * 1,2$ & 0.401 & 0.686 & 0.126 & 0.611 & 0.349 & 0.340 \\
\hline$K M * 3$ & 0.599 & 0.314 & 0.874 & 0.389 & 0.651 & 0.660 \\
\hline$H$ & 0.480 & 0.431 & 0.220 & 0.475 & 0.454 & 0.449 \\
\hline Average $H$ & 0.469 & 0.468 & 0.465 & 0.395 & 0.414 & 0.577 \\
\hline
\end{tabular}


Fig. 1. Geographic location of the five French Guiana and one Brazilian Indian populations considered and the South American Native populations compared Abbreviations: ACH Aché ; ASU Asurini ; CAI Caingang ; CHO Choroti ; CIN Cinta Larga ; GUA Guarani ; KAO Kararaô ; KAR Karitiana ; MAP Mapuche ; MAT Mataco ; PAR Parakanã ; QUE Quechua ; SUR Surui ; TEN Tenharim ; TOB Toba ; URU Urubu-Kaapor ; XAV Xavante

Fig. 2. Correspondence analysis for the six populations studied considering 11 systems $(\mathrm{MN}, \mathrm{Ss}$, Rh, P, Duffy, PGM1, ACP, GC, HP, Gm, and Km)

Fig. 3. Correspondence analysis for 23 South American populations considering seven systems (MN, Ss, Rh, PGM1, P, HP, and Duffy).

Fig. 4. Synthetic map according to axis 1 of Figure 3.

Fig. 5. Synthetic map according to axis 2 of Figure 3. 


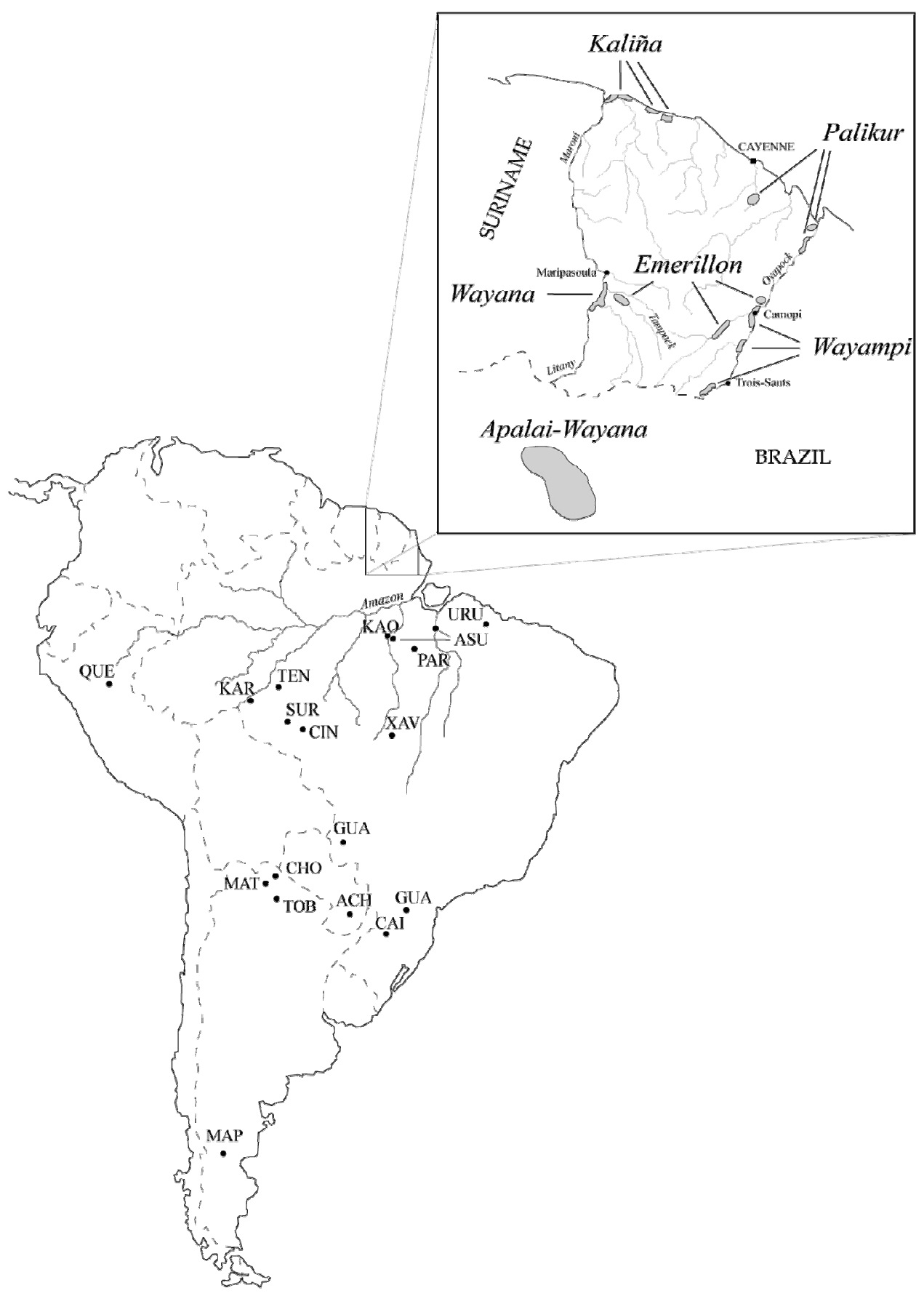

Figure 1 


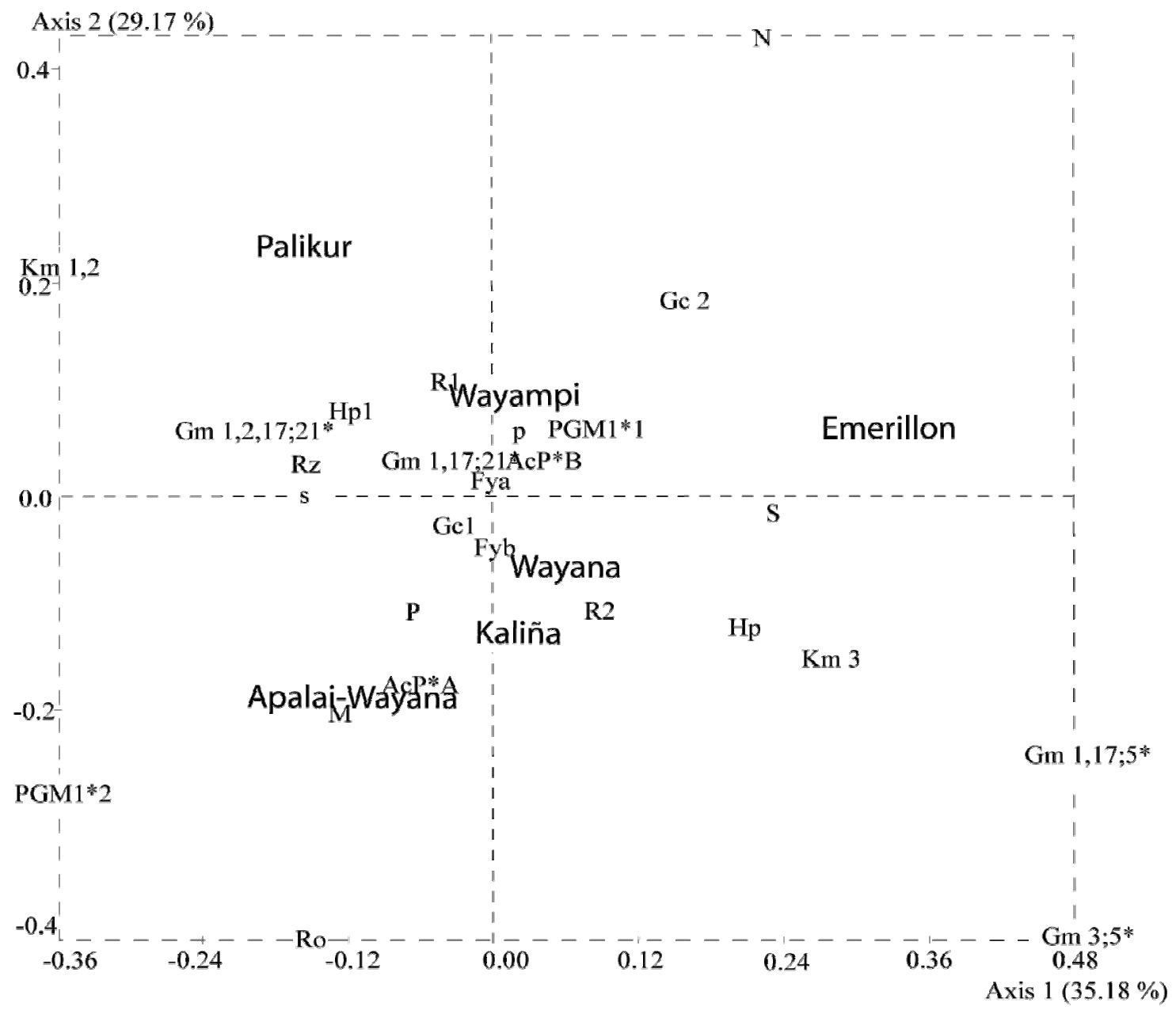

Figure 2 


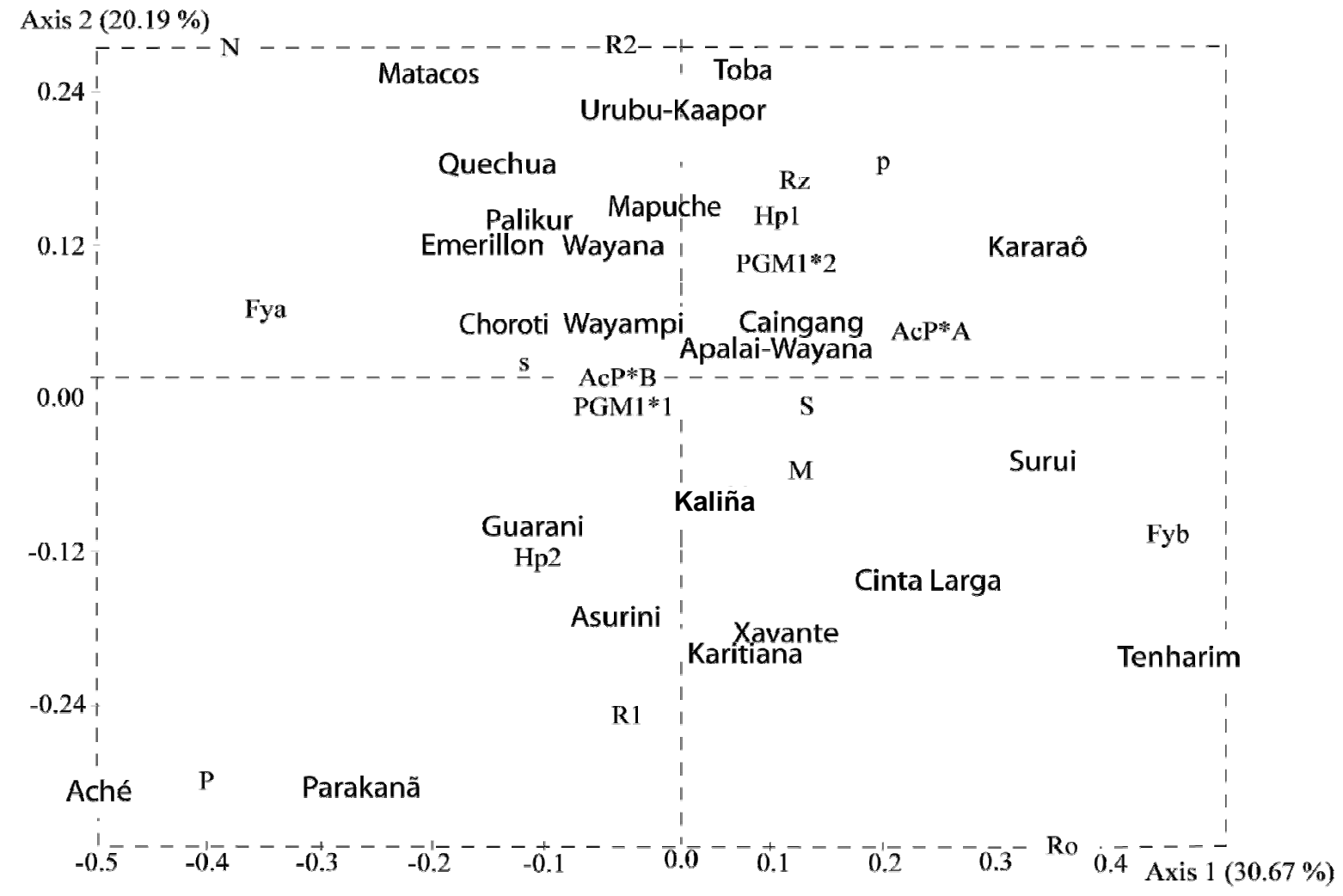

Figure 3 


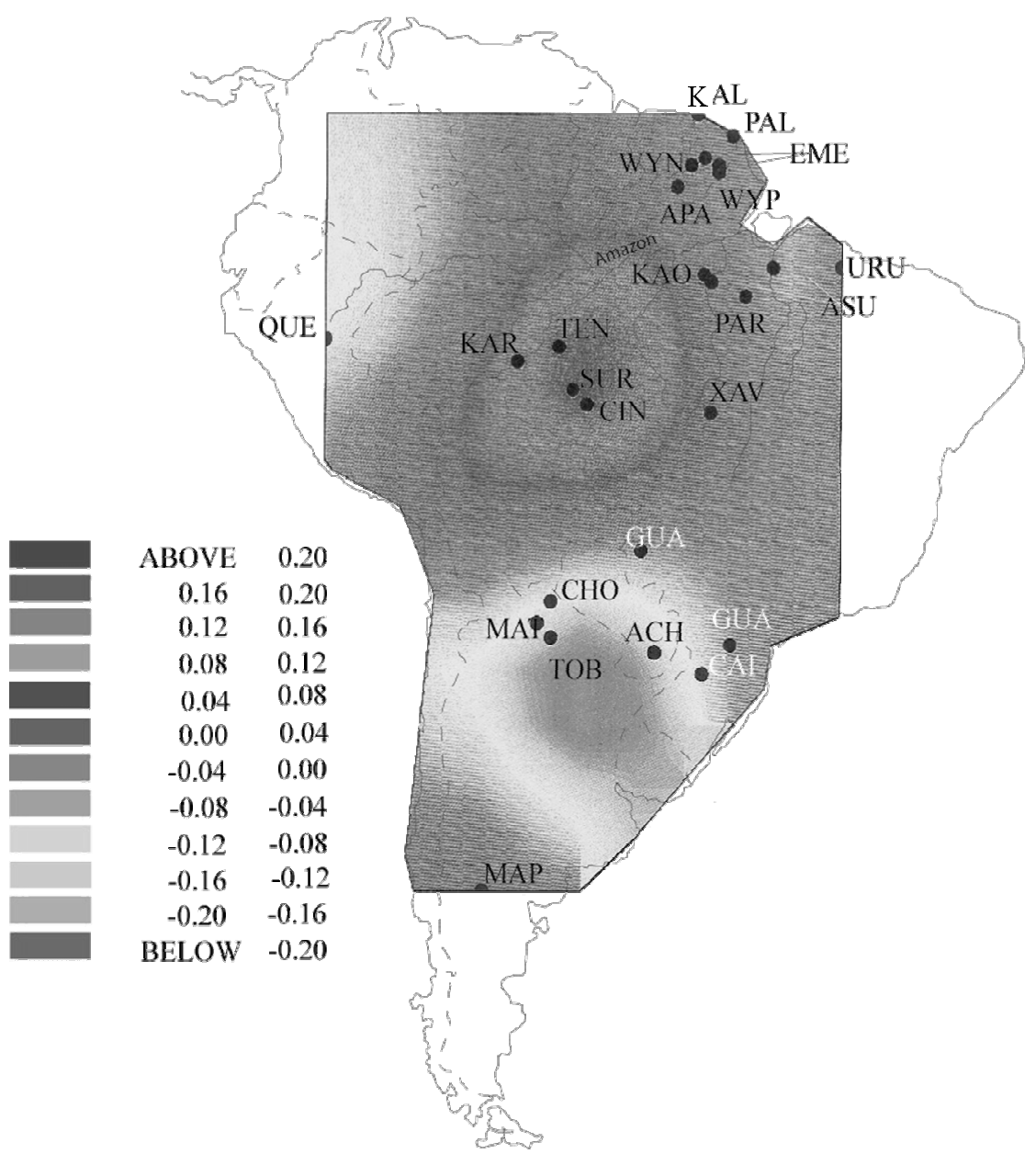

Figure 4 


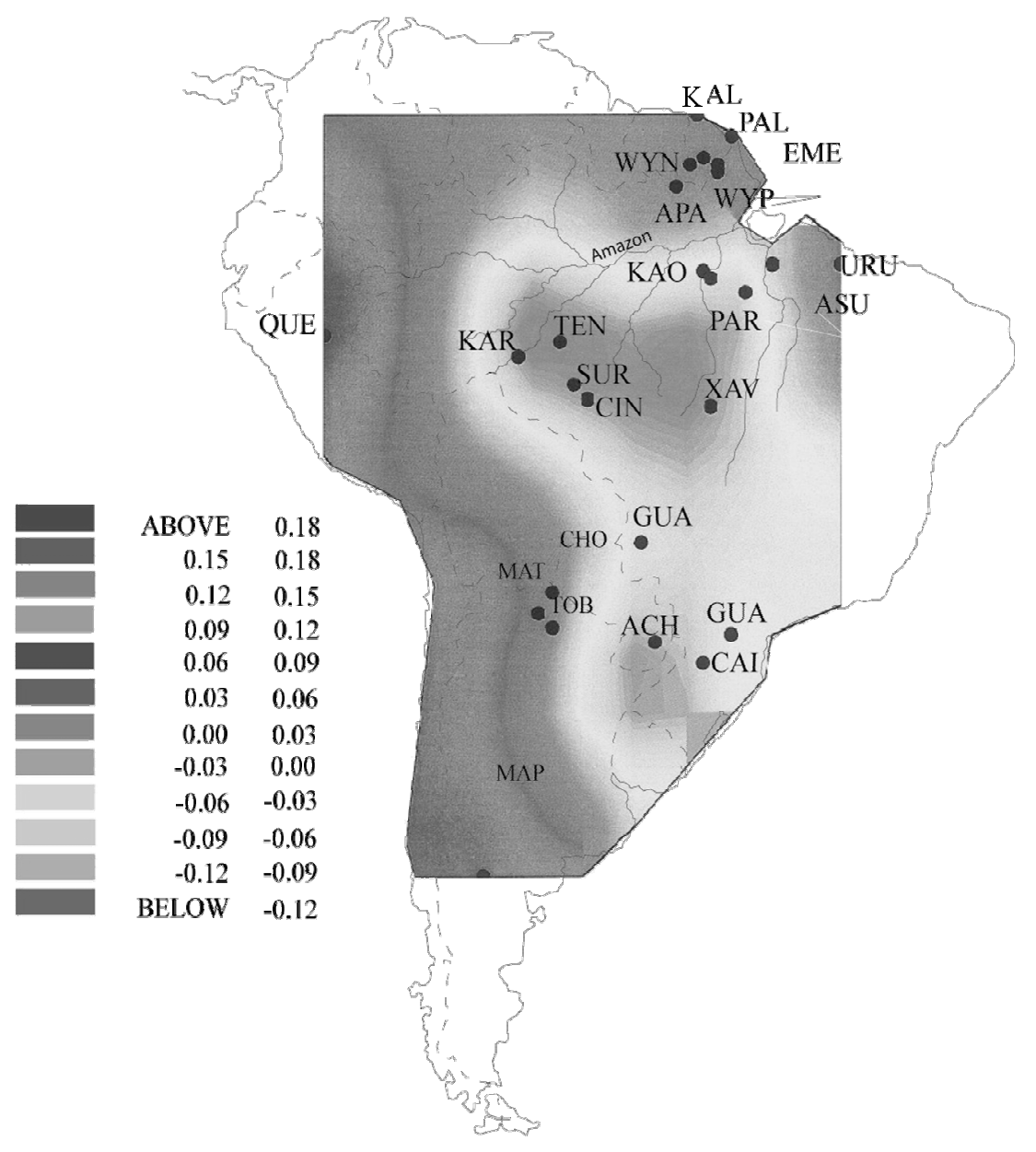

Figure 5 